\title{
Elaboration of garlic and salt spice with reduced sodium intake
}

\author{
JÉSSICA F. RODRIGUES, GABRIELA JUNQUEIRA, CARLA S. GONÇALVES, \\ JOÃO D.S. CARNEIRO, ANA CARLA M. PINHEIRO and CLEITON A. NUNES \\ Departamento de Ciência dos Alimentos, Universidade Federal de Lavras, \\ Campus Universitário, Caixa Postal 3037, 37200-000 Lavras, MG, Brasil \\ Manuscript received on November 25, 2013; accepted for publication on May 5, 2014
}

\begin{abstract}
Garlic and salt spice is widely used in Brazilian cookery, but it has a high sodium content; as high sodium intake has been strongly correlated to the incidence of chronic diseases. This study aimed to develop a garlic and salt spice with reduced sodium intake. Sensory evaluation was conducted by applying the spices to cooked rice. First, the optimal concentration of spice added during rice preparation was determined. Subsequently, seasonings (3:1) were prepared containing $0 \%, 50 \%$ and $25 \%$ less $\mathrm{NaCl}$ using a mixture of salts consisting of $\mathrm{KCl}$ and monosodium glutamate; a seasoning with a $0 \% \mathrm{NaCl}$ reduction was established as a control. Three formulations of rice with different spices were assessed according to sensory testing acceptance, time-intensity and temporal domain of sensations. The proportions of salts used in the garlic and salt spice did not generate a strange or bad taste in the products; instead, the mixtures were less salty. However, the seasonings with lower sodium levels (F2 and F3) were better accepted in comparison to the traditional seasoning (F1). Therefore, a mixture of $\mathrm{NaCl}, \mathrm{KCl}$ and monosodium glutamate is a viable alternative to develop a garlic and salt spice with reduced sodium intake.
\end{abstract}

Key words: $\mathrm{KCl}$, monosodium glutamate, TDS, TI.

\section{INTRODUCTION}

Salt is an additive with a long history and is primarily used in cooking and the food industry. This compound imparts a salty taste and is a characteristic spice in food. In addition to its sensory characteristics, salt also reduces microbial activity by decreasing the active water content in food, preventing deterioration and making certain foods safe for consumption (Cruz et al. 2011). However, excessive $\mathrm{NaCl}$ consumption has been associated with an increased risk of hypertension, cardiovascular disease, osteoporosis and kidney

Correspondence to: Jéssica Ferreira Rodrigues

E-mail: jessikfr5@hotmail.com stones (Sihufe et al. 2003, Heaney 2006). Thus, besides encouraging people to read food labels and choose low sodium products (Petersen et al. 2013), the development of new products with reduced sodium content is also very important.

According to a Brazilian newspaper, Folha de São Paulo, the ABIA (Brazilian Association of Food Industries), which was approved by the Ministry of Health in 2013, concluded that most of the sodium consumed by Brazilians came from both processed foods and the cooking salt and seasonings added at home. In addition, a survey administered by the Ministry of Health (2011) found that Brazilians consume $12 \mathrm{~g}$ sodium chloride / day (4800 mg 
$\mathrm{Na}$ / day) on average; however, the healthy limit established by the World Health Organization(WHO) is $5 \mathrm{~g}$ of sodium chloride per day, corresponding to approximately $2000 \mathrm{mg}$ of sodium per day. Therefore, the Ministry of Health and the Brazilian food industry agreed to reduce the sodium content of various food categories by 2016 (WASH 2012).

Because several products need to adhere to the lowered sodium regulations, including garlic seasoning salt, reducing the sodium content is extremely important since these products are used in most culinary preparations. One word, reducing the sodium content in food products is challenging because decreasing the $\mathrm{NaCl}$ content is associated with a decrease in acceptance of the modified product (Toldrá 2006).

Several $\mathrm{NaCl}$ substitutes have been studied; potassium chloride stands out due to having physical properties similar to those of $\mathrm{NaCl}$. However, completely replacing $\mathrm{NaCl}$ with $\mathrm{KCl}$ is not recommended because a bitter taste is imparted to the products, rendering them inacceptable (Nascimento et al. 2007). Therefore, combining salts during the preparation of products with reduced sodium and sensory acceptance is an interesting solution.

Another interesting alternative used to reduce the sodium content in foods is incorporating flavor enhancers, such as monosodium glutamate (Brandsma 2006). Mojet et al. (2004) showed that enhancing the umami taste increases the perception of the saltiness of food; therefore, foods containing a high content of umami substances may allow for a lower $\mathrm{NaCl}$ content without decreasing consumer acceptance.

Replacement salts containing potassium, magnesium, and calcium have been investigated in several products (Katsiari et al. 2001, Johnson et al. 2009, Ayyash and Shah 2011, Souza et al. 2012, Canto et al. 2014). Grummer et al. (2012) showed that potassium chloride could be used successfully to achieve large reductions in sodium when replacing a portion of the $\mathrm{NaCl}$ in Cheddar cheese. It is possible to produce this low sodium Cheddar cheese in a way that results in high consumer acceptance and low bitterness (Grummer et al. 2013). Kamleh et al. (2012) and Karimi et al. (2012) also demonstrated that Halloumi cheese and feta cheese could be successfully manufactured using $\mathrm{NaCl} / \mathrm{KCl}$. Kamleh et al. (2012) suggested that using ingredients that would help mask this bitterness, would improve the acceptability of Halloumi. Campagnol et al. (2012) showed that it is possible to produce fermented sausages with $50 \%$ replecement with $\mathrm{KCl}$ and with addition of lysine with sensorial quality and Dos Santos et al. (2013) showed that the reformulated sausages containing monosodium glutamate combined with lysine, taurine, disodium inosinate and disodium guanylate masked the undesirable sensory attributes associated with the replacement of $50 \%$ and $75 \% \mathrm{NaCl}$ with $\mathrm{KCl}$, enabling the production of fermented cooked sausages with good sensory acceptance and approximately $68 \%$ sodium reduction.

Furthermore, Drake et al. (2011) studied the sodium-reduction in cheese sauce, cottage cheese, and milk-based soup and they found that the complexity of the food matrix, influenced salty taste perception in addition to the percentage sodium reduction that was noticeable to consumers. Thus, further research for each product is necessary to further clarify salty taste perception.

Replacing $\mathrm{NaCl}$ with other salts leads to several possibilities regarding the reduction of saltiness and leads to the introduction of a metallic, bitter or astringent taste. Therefore, it is necessary that, in addition to acceptance sensory tests, tests such as analyses of the temporal dominance of sensations (TDS) and time-intensity (TI) must be performed to characterize the sensory profile of the product during its intake.

The objective of this study was to prepare a seasoning and garlic salt with a low sodium content using various mixtures of salts, including $\mathrm{NaCl}, \mathrm{KCl}$ and monosodium glutamate. Additionally, sensory tests and evaluations of temporal acceptance (TI and TDS) were performed. 


\section{MATERIALS AND METHODS}

The study (CAAE: 18827013.8.0000.5148) was reviewed and approved by the Ethics Committee of the Federal University of Lavras (Protocol 363 827).

\section{Preparation of the Product}

\section{Garlic and salt spice}

The materials used during food preparation in this study included the following: garlic, potassium chloride $\left(99 \%\right.$ Vetec $^{\circledR}$, Rio de Janeiro - RJ, Brazil), monosodium glutamate $\left(99 \%\right.$ Aji-no-moto ${ }^{\circledR}$, São Paulo - SP, Brazil) and sodium chloride (99\% $\operatorname{Vetec}^{\circledR}$, Rio de Janeiro - RJ, Brazil). Each spice mixture was prepared in a 3:1 ratio (salt:garlic). The garlic was crushed and mixed with salt in a Walita brand multiprocessor.

\section{Rice}

Every formulation was prepared with rice and garlic seasoning salt in cooker using three parts water to one part rice.

SENSORIAL ANALYSIS

\section{Just-about-right-scale}

To perform the sensory tests and optimize the spice content in the rice, the concentrations were determined during pre-testing: the rice formulations were prepared using $1 \%, 4 \%, 7 \%$ and $10 \%$ of garlic and salt spice composed of three parts salt to one part garlic.

The optimal spice concentration was determined using sensory tests with an ideal scale (Justabout-right-scale), using a scale of five points. During the analysis, 60 panelists evaluated the samples and recorded their responses on a specific scale based on how perfect these samples were regarding the salty taste using the method reported by Vickers (1998). The method proposes that the panelists have to evaluate the samples according to an unstructured line scale anchored with "not nearly salty enough" at the left, "just right" at the center, and "much too salty" at the right was used to optimize saltiness in the garlic and salt spice.

The responses were converted into numerical values and analyzed via regression analysis in a SISVAR program (Ferreira 2002).

Through the results of the jus-about-righscale, three garlic and salt spice formulations were prepared from the results of the pre-tests: formulation 1 - $0 \% \mathrm{NaCl}$ reduction; formulation 2 $25 \% \mathrm{NaCl}$ reduction and formulation $3-50 \% \mathrm{NaCl}$ reduction (Table I).

TABLE I

Ingredients used to produce the garlic seasoning and salt (3:1) per 100g.

\begin{tabular}{cccccc}
\hline Rice & Spice & NaCl & KCl & Glu & Garlic \\
\hline F1 & Spice1 & $2,4375 \mathrm{~g}$ & - & - & $0,8125 \mathrm{~g}$ \\
F2 & Spice2 & $1,8281 \mathrm{~g}$ & $0,5246 \mathrm{~g}$ & $0,3266 \mathrm{~g}$ & $0,8931 \mathrm{~g}$ \\
F3 & Spice3 & $1,2188 \mathrm{~g}$ & $0,3497 \mathrm{~g}$ & $1,3064 \mathrm{~g}$ & $0,9583 \mathrm{~g}$ \\
\hline
\end{tabular}

\section{TIME-INTENSITY}

For the sensory panel analysis of time-intensity, 28 participants (fourteen men and fourteen women aged 24-56 with experience in sensory evaluation who consumed garlic and salt spice at least once a week and who had interest and time availability were selected for the sensory panel analysis of time-intensity through the use of questionnaires. For acquisition of data and subsequent analysis, the SensoMaker program was used (Nunes and Pinheiro 2012). Through a graphical interface in the form of a 10-point scale, with 0 meaning no perception and 10 signifying an extreme perception of salty taste, each panelist indicated the intensity of the attribute of each sample. The samples were presented in a monadic way, using a balanced complete block design (Wakeling and MacFie 1989) by mouse stimulus. During the analysis, warning messages were presented before each step with instructions regarding the action to be performed (Cardello et al. 2003). First, the panelist clicked on the "start" 
button and took the full amount of the sample during two seconds, then, for an additional 20 seconds, indicated the intensity of the particular sensory attribute (salty flavor) on the scale. Finishing the analysis a message indicated the end of the test and the panelist proceeded to another sample.

The software SensoMaker analyzed the data collected during each sensory evaluation session and generated the parameters: Imax (maximum intensity recorded by the assessor); TImax (time in which the maximum intensity was recorded) (Palazzo and Bolini 2009). The data are presented in graphical form (through calculation parameters) using the Microsoft Excel 2012. In the graphs, the horizontal axis denoted time, while the vertical axis displayed the intensity values.

\section{TEMPORAL DOMINANCE OF SENSATIONS (TDS)}

We recruited 28 participants for the TDS analysis. To recruit the participants, questionnaires were administered to assess the consumption of garlic and salt spice (at least once a week) and experience with sensory analysis. The panelists were trained regarding the temporality of sensations (TDS) and were introduced to the SensoMaker data acquisition program (Nunes and Pinheiro 2012). The total duration of the experiment was $20 \mathrm{~s}$, and the attributes selected for the panel were determined using the conventional method: salty, bitter, sweet, umami, sour, spicy, astringent and off-taste.

After the instructions, the panelists were asked to click on the "start" button and during two seconds to put the sample of rice (approximately $5 \mathrm{~g}$ ) in their mouths and immediately start the evaluation. During twenty seconds, using the mouse, the participants were requested to select the dominant taste over the time. They were told that the dominant taste is the taste that is perceived with the greatest clarity and intensity. For each of these eight descriptors a button on the computer screen was presented for evaluation.
The presentation was made in monadic order (Macfie et al. 1989) in disposable white plastic cups coded with three-digit numbers. The samples were served one by one, and the assessors were asked to rinse their mouth with water between each sample.

The methodology described by Pineau et al. (2009) was used in combination with the SensoMaker software to compute the TDS curves. The curves were ploted using a smooth equal $5 \%$ and they were used for visual interpretation. Briefly, two lines are drawn in the TDS graphical display: the "chance level" and the "significance level". The "chance level" is the dominance rate that an attribute can obtain by chance and the "significance level" is the minimum value this proportion should equal, in order to consider significant (Pineau et al. 2009). The "chance level" and "significance level" are calculated using the confidence interval of a binomial proportion based on a normal approximation according to Pineau et al. 2009 (1).

$$
\mathrm{Ps}=\mathrm{P}_{0}+1.645 \sqrt{\frac{P_{0}\left(1-P_{0}\right)}{n}}
$$

Ps is a significantly lower ratio value $(a=0.05)$ at any point in time for a TDS curve, and $n$ is the number of subjects * replication.

Analogous to the parameters of the TI curves, three parameters of the TDS curves for the attribute salty were extracted, namely maximum dominance rate, duration of the salty dominance and area under the curve. Duration of the salty dominance and TDS area were calculated only above the chance level ( $p=1$ /number of attributes; here: $p=12.5 \%$ ) in order to exclude interference. Calculation of the dominance rates was conducted using SensoMaker software. For further analyses the data were exported to Microdoft Excel and the graphs were ploted. The evaluation process according to Pineau et al. (2009) suggests summarising the data for all evaluations. 
To analyze the results of the curves significant sensations were considered, i.e. above the line "significant level". Curves were analyzed through the maximum rate of dominance, time of the maximum rate of dominance and area under the curve.

\section{ACCEPTANCE TEST}

The spices were analyzed using a sensory acceptance test with cooked rice incorporating the spice concentration found during the just-about-right-scale test, as previously reported by Fortes et al. (2012).

The samples were served in four sections, and the order of presentation was balanced according to the work of Wakeling and Mcfie (1995). The test was conducted in individual booths. The panelists received approximately $20 \mathrm{~g}$ of each sample in plastic cups coded with three-digit numbers. The test was performed with proper lighting and without interferences, such as noise and odors (Bowles and Demiate 2006).

Sixty judges evaluated the samples compared to the acceptance salty flavor and overall impression using a nine-point hedonic scale ranging from "extreme dislike" to "extreme like", similar to the methodology described by Stone and Sidel (1993).

The results of the acceptance test were subjected to an analysis of variance in SISVAR (Ferreira 2002). To visualize the acceptance of the samples, histograms were constructed to display the frequency distribution of the hedonic values obtained for each sample. The histograms enabled the visualization of the grouped hedonic values for each sample, revealing the level of acceptance and rejection to compare the performances of two or more samples (Behrens et al. 1999).

\section{RESULTS AND DISCUSSION}

\section{JUST-ABOUT-RIGHT-SCALE}

The linear model $\mathrm{Y}=0.805837 \mathrm{X}+0.381925$ (Figure 1) described the relationship between the ideal formulations of rice and seasoning (Table I).
The percentage of explained variance $\left(R^{2}\right)$ for the model was satisfactory $\left(\mathrm{R}^{2}=99.5 \%\right)$, revealing good agreement between the experimental and modeled data.

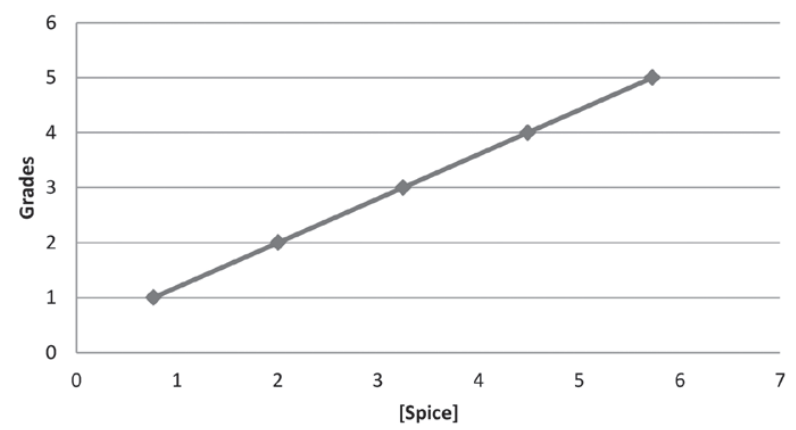

Figure 1 - Regression analysis of the results obtained in the Just-about-right-scale test.

The equation of the line was used to determine that the optimal concentration ( $\mathrm{Y}=3$ ) of spice (3:1) added to rice is $3.25 \%$. Fortes et al. (2008) found that using 3\% salt while preparing conventional rice promotes better acceptance.

Therefore, the calculations for the reduced$\mathrm{NaCl}$ seasoning (Table I) were based on their optimal concentration, while maintaining the 3:1 ratio (salt: flavor).

Seasonings 2 and 3 were made with a $25 \%$ and $50 \% \mathrm{NaCl}$ reduction, respectively, while seasoning 1 was the control $(0 \%$ reduction $\mathrm{NaCl})$. The concentrations of $\mathrm{KCl}$ and monosodium glutamate used to replace $\mathrm{NaCl}$ were determined during pre-testing.

\section{TIME-INTENSITY}

The evaluation of the salty taste of the garlic and salt spice through time-intensity analysis is very important, because the use of other salts to replace $\mathrm{NaCl}$ can promote a decreased perception of the salty taste in the product. So through this test it is possible to find what the best substitutes of $\mathrm{NaCl}$ are and what the best concentrations of each one are. Figure 2 and Table II show the charts and the 
parameters obtained for the analysis of the salty taste intensity over time for the rice formulations prepared with garlic and salt spices with varied sodium contents.

The analysis of variance applied to the parameters obtained while analyzing the intensity over time indicated that there was a significant difference $(p>0.05)$ between the maximum saltiness intensity (Imax) and the time needed to achieve the maximum saltiness intensity (TI Max.).

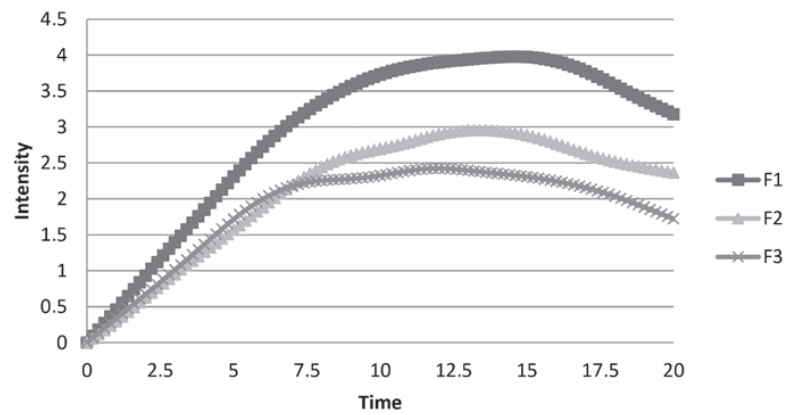

Figure 2 - Graphical representation of the intensity of the salty flavor over time for rice seasoned with reduced sodium formulations (F1: $0 \%$ reduction $\mathrm{NaCl} ; \mathrm{F} 2$ : $25 \%$ reduction $\mathrm{NaCl}$; F3: 50\% reduction $\mathrm{NaCl}$ ).

TABLE II

Parameters obtained while analyzing the intensity over time for the salty taste of the garlic and salt spice.

\begin{tabular}{ccc}
\hline Samples & $\begin{array}{c}\text { Imax (Maximum } \\
\text { of saltiness) }\end{array}$ & $\begin{array}{c}\text { TI Max (elapsed time to } \\
\text { reach the maximum } \\
\text { intensity of saltiness) }\end{array}$ \\
\hline F1 & $3.98^{\mathrm{a}}$ & $14.6^{\mathrm{a}}$ \\
F2 & $2.96^{\mathrm{b}}$ & $13.4^{\mathrm{b}}$ \\
F3 & $2.42^{\mathrm{c}}$ & $12^{\mathrm{c}}$ \\
\hline
\end{tabular}

Values marked with the same letters are not significantly different at a $5 \%$ probability when using Tukey's test. (F1: $0 \%$ reduction $\mathrm{NaCl} ; \mathrm{F} 2: 25 \%$ reduction $\mathrm{NaCl} ; \mathrm{F} 3$ : reduction of $50 \% \mathrm{NaCl}$ ).

Figure 2 and Table II indicate that all formulations showed a similar profile and achieved maximum saltiness within 12 to 15 seconds. However, replacing $\mathrm{NaCl}$ with $\mathrm{KCl}$ and monosodium glutamate generated a less intense salty flavor relative to the control (F1). The same was observed by Souza et al. (2013) and Teodoro et al. (2013) in their experiment with sodium reduction in butter and in cream cheese. However, these studies showed that potassium chloride salt is more similar to $\mathrm{NaCl}$ than monosodium glutamate. Therefore, according to Guinee and O'Kennedy (2007), the substitution of up to $40 \%$ of the $\mathrm{NaCl}$ for $\mathrm{KCl}$ is a good alternative to reduce the sodium content and maintain the characteristic flavor of cheeses. Formulation 1 demonstrated a maximum intensity of salty flavor equal to approximately 3.98, while the formulations F2 and F3 had intensities equal to approximately 2.96 and 2.42 , respectively.

According to Formaker and Hill (1988) and Mattes (2001), the perception of the salty taste of sodium chloride is attributed to both the cation (70-85\%) and the anion (30-15\%) due to the passage of ions through a narrow ion channel. According to Mccaughy (2007), these channels are specific for sodium chloride, and it is difficult to find other non-toxic substances with this capability. Therefore, the capacity depends on the types of cations and anions present in the substance (Ye et al. 1991, 1993). Compared to sodium chloride, the flavor perception of other cations such as potassium is less salty (Mooster 1980), as observed in this experiment.

Souza et al. (2013) observed that for sodium chloride substitutes in butter, potassium chloride had similar intensity to that of $\mathrm{NaCl}$, while higher concentrations of monosodium glutamate were required to obtain a similar salty taste. This justifies the lowest salty power observed in the formulation with the $50 \%$ less $\mathrm{NaCl}$ (F3); this mixture contained more monosodium glutamate and less $\mathrm{KCl}$.

\section{TEMPORAL DOMINANCE OF SENSATIONS}

Similar to TI test, the temporal dominance of sensations test is also important to describe the desirable and undesirable sensations of the products with reduced sodium. 
The dominant temporal profiles of sensations (TDS) for the 3 rice formulations are plotted in Figure 3, 4 and 5. Each curve represents a particular attribute of dominance over the course of time. In the graphical representation of the TDS analysis, two lines are shown: the 'chance level' and 'significance level'. The 'chance level' is the dominance rate that an attribute can obtain by chance, and the 'significance level' is the minimum value the dominance rate should equal to be considered significant (Pineau et al. 2009).

For the TDS prepared rice seasoned with F1, the salty taste dominated the entire analysis. In the rice seasoned with F2, salty and sweet flavors were dominant, and the salty taste lasted longer (11s) and overwhelmed the sweet taste.

The TDS curves also show that F1 reached a maximum dominance of approximately 0.6 (maximum $60 \%$ of the panelists selected this mixture as the saltiest) for salinity, while F2 reached a maximum of 0.35 salinity. Therefore, the duration and the maximum rate salt prepared using a $0 \% \mathrm{NaCl}$ reduction rather than that prepared with $25 \%$ less $\mathrm{NaCl}$ because $\mathrm{KCl}$ and glutamate are less salty than $\mathrm{NaCl}$ (Souza et al. 2013).

In the formulation prepared with $50 \%$ less $\mathrm{NaCl}$ (F3), we observed a dominant umami taste; this observation is attributed to the higher concentration of monosodium glutamate (Solms 1969, Kawamura and Kare 1987) used to replace $\mathrm{NaCl}$. In addition, a slight sweet taste was detected for approximately $2 \mathrm{~s}$. Although there are many salt substitutes on the market, according to Cruz et al. (2013), sodium chloride is the only one that promotes the manifestation of a pure salty taste.

According to Souza et al. (2013) the salt power of glutamate $(31.59 \%)$ is well below that of sodium chloride; three times more sodium glutamate is needed to match the salty flavor of $\mathrm{NaCl}$, explaining the absence of perceived saltiness in the F3 tasters. In addition, the same authors found in their work with butter that completely replacing $\mathrm{NaCl}$ with monosodium glutamate altered the expression of

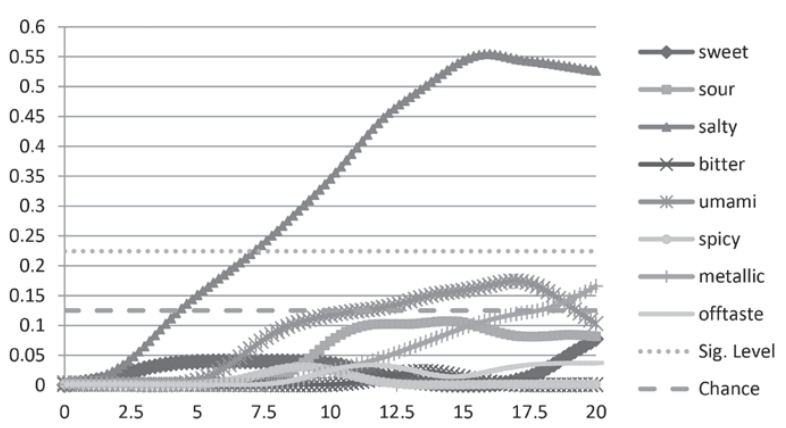

Figure 3 - Graphical representation of the temporal profile of dominance for the sensations generated by the rice seasoned with spice $1(\mathrm{~F} 1: 0 \%$ reduction of $\mathrm{NaCl})$.

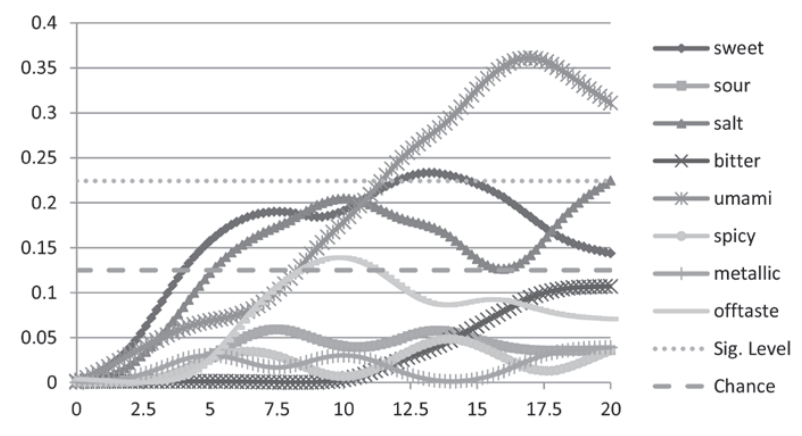

Figure 4 - Graphical representation of the temporal profile of dominance for the sensations generated by the rice seasoned with spice 2 (F2: $25 \%$ reduction of $\mathrm{NaCl}$ ).

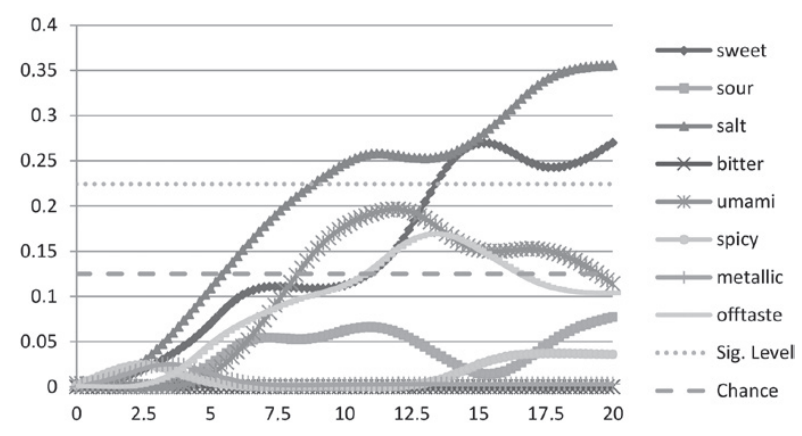

Figure 5 - Graphical representation of the temporal profile of dominance for the sensations generated by the rice seasoned with spice 3 (F3: $50 \%$ reduction of $\mathrm{NaCl}$ ).

salty, sweet and umami flavors; the latter two were also reported during the analyses of TDS for the formulations containing 25 and $50 \%$ less $\mathrm{NaCl}$, in addition to monosodium glutamate (F2 and F3). 
Sensory characteristics, functional properties and shelf life are the features most affected by the reduction of salt in food (Guinee and O'Kennedy 2007). Thus, in the development of products with reduced sodium, it is important to consider the nature and composition of the product, the type of treatment and the manufacturing conditions (Ruusunen and Puolanne 2005).

\section{ACCEPTANCE TEST}

The analysis of variance applied to the acceptance testing data indicated that there was no significant difference $(p>0.05)$ in relation to the acceptance of the formulations of mozzarella regarding the attributes. Figure 6 and 7 show histograms obtained from the data for acceptance testing of spices for a better view of the acceptance of the formulations.

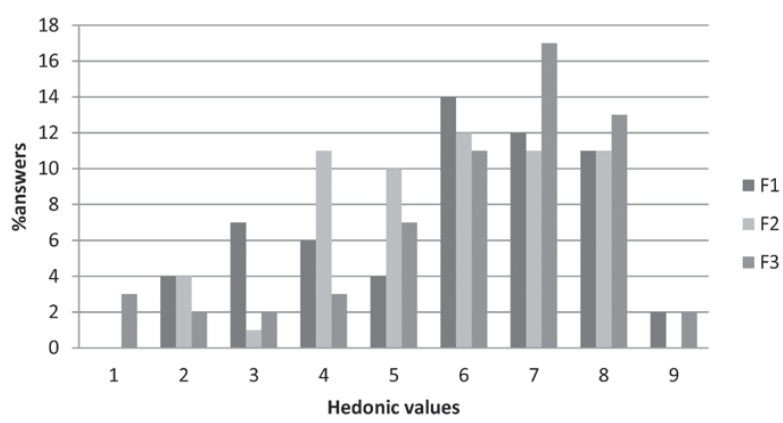

Figure 6 - Histogram displaying the frequencies of the hedonic values for acceptance against the saltiness of the rice seasoned with reduced sodium content formulations (F1: $0 \%$ reduction of $\mathrm{NaCl} ; \mathrm{F} 2: 25 \%$ reduction of $\mathrm{NaCl} ; \mathrm{F} 3: 50 \%$ reduction $\mathrm{NaCl}$ ).

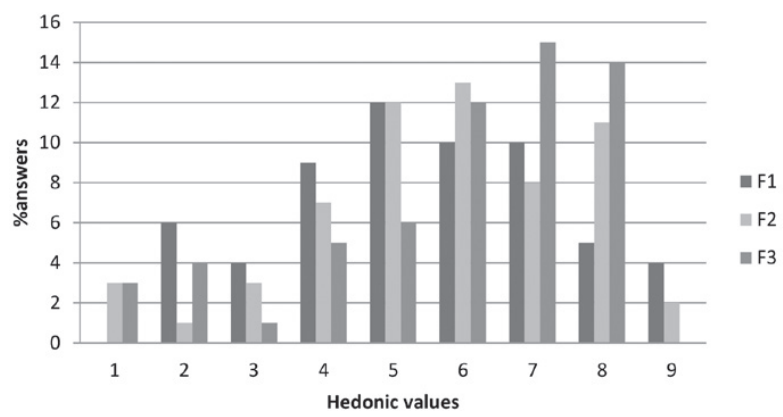

Figure 7 - Histogram displaying the frequencies of the hedonic values for acceptance against the overall impression of the rice seasoned with reduced sodium content formulations (F1: $0 \%$ reduction of $\mathrm{NaCl} ; \mathrm{F} 2: 25 \%$ reduction of $\mathrm{NaCl} ; \mathrm{F} 3$ : $50 \%$ reduction $\mathrm{NaCl}$ ).
The histograms revealed slight differences in the frequency distribution for the hedonic values assigned to the different rice formulations. Note that in both attributes, the frequency distributions of the responses for all samples skewed toward the region of the highest scores, ranging from "like slightly" (note 6) and "like extremely" (note 9), indicating a good acceptance of the products. Therefore, a replacement of $25 \%(\mathrm{~F} 2)$ and $50 \%(\mathrm{~F} 3)$ of $\mathrm{NaCl}$ by $\mathrm{KCl}$ and monosodium glutamate in garlic and salt spice promoted the development of products with the same sensory acceptability as the traditional one. Furthermore, formulation F3 had acceptance notes higher than other products.

According to Brandsma (2006), flavor enhancers are interesting to the food industry because they can help reduce the sodium chloride levels. Similarly, for formulation 3, using a spice with a higher concentration of monosodium glutamate led to higher scores for acceptance attributes among students. In both histograms, the frequency distributions of the responses for all of the samples were displaced to the region of highest scores, indicating good acceptance of products.

Several recent studies have lead to the development of products with less sodium and good acceptability, but in every case, a partial substitution of sodium chloride was enacted using different mixtures of salts (Katsiari et al. 2001, Guinee and O'Kennedy 2007, Horita et al. 2011). The histograms indicated that all samples achieved similar results. Therefore, a reduction of up to $50 \%$ of $\mathrm{NaCl}$ in seasoning and garlic salt composed of $\mathrm{NaCl}, \mathrm{KCl}$ and monosodium glutamate did not adversely affect the acceptance of the product, when compared to the control.

Furthermore, through the acceptance results, another alternative to promote the reduction of sodium in garlic and salt spice is the simple reduction of $\mathrm{NaCl}$ content used during its preparation. According to Ares et al. (2014), this is possible, since consumers have become 
increasingly concerned with the concept of "wellbeing" and the human health risk factors. So, they have sought healthier products with lower salt content (Drake et al. 2011). In addition, salt awareness campaigns are needed (Kenten et al. 2013). Moreover, while some aspects of salt reduction can be globally implemented, local tailoring is required to match levels of interest in salt reduction (Newson et al. 2013). Strategies have been suggested by Mendoza et al. (2014).

\section{CONCLUSION}

It is possible to produce a garlic and salt spice with replacement of up to $50 \%$ of $\mathrm{NaCl}$ by $\mathrm{KCl}$ and monosodium glutamate, even though the products result in lower intensities of saltiness and umami taste manifestation.

TDS and TI analyses are important tools in the development of products with reduced sodium intake. Through this analysis it was possible to describe the sensorial profile of the products and to optimize the formulations.

\section{RESUMO}

O tempero alho e sal é amplamente utilizado na culinária brasileira, mas possui um alto teor de sódio. Como a alta ingestão de sódio tem sido fortemente correlacionada com a incidência de doenças crônicas, este estudo teve como objetivo desenvolver um tempero alho e sal com teor de sódio reduzido. A avaliação sensorial dos temperos foi conduzida através da aplicação dos mesmos ao arroz cozido. Primeiramente, a concentração ótima de tempero adicionado durante a preparação do arroz foi determinada. Subseqüentemente, temperos (3:1) foram preparadas contendo $0 \%, 50 \%$ e $25 \%$ de redução de $\mathrm{NaCl}$, utilizando uma mistura de sais contendo $\mathrm{KCl}$ e glutamato monossódico. Um tempero com $0 \%$ de redução de $\mathrm{NaCl}$ foi estabelecido como controle. Três formulações de arroz elaboradas com os diferentes temperos foram avaliadas pelo teste de aceitação sensorial, tempo-intensidade e domínio temporal das sensações. As proporções de sais utilizadas no tempero alho e sal não geraram gostos estranhos ou ruins aos produtos, mas surtiram em produtos menos salgados. No entanto, os temperos com níveis mais baixos de sódio (F2 e F3) foram melhor aceitos em comparação ao tempero tradicional (F1). Portanto, uma mistura de $\mathrm{NaCl}, \mathrm{KCl}$ e glutamato monossódico é uma alternativa viável para desenvolver um tempero alho e sal com reduzido teor de sódio.

Palavras-chave: $\mathrm{KCl}$, glutamato monossódico, TDS, TI.

\section{REFERENCES}

Ares G, SAldamando L, Giménez A AND Deliza R. 2014. Food and wellbeing. Towards a consumer-based approach. Appetite 74: 61-69.

AYYASH MM AND SHAH NP. 2011. The effect of substitution of $\mathrm{NaCl}$ with $\mathrm{KCl}$ on chemical composition and functional properties of low-moisture Mozzarella cheese. J Dairy Sci 94: 3761-3768.

Behrens JH, DA SiLva MAAP AND WAKELING IN. 1999. Affective sensory tests and internal analysis of preference in acceptability assessment of Brazilian varietal white wines. Ciênc Tecnol Aliment 19(2): 214-220.

Bowles S AND Demiate IM. 2006. Caracterização físicoquimica de okara em aplicação em pães do tipo francês. Ciênc Tecnol Aliment 26: 653-659.

BRANDSMA I. 2006. Reducing sodium. A European perspective attitudes and regulations regarding sodium in foods pose challenges for the food industry. Food Technol-Chicago 60: 24-29.

CAmpagnol PCB, Santos BAC, Terra NN and Pollonio MAR. 2012. Lysine, disodium guanylate and disodium inosinate as flavor enhancers in low-sodium fermented sausages. Meat Sci 91: 334-338.

CANTO ACVCS, Lima BRCC, Suman SP, Lazaro CA, Monteiro MLG, CONTE-Junior CA, FreitAs MQ, CRUZ AG, SANTos EB AND Siolva TJP. 2014. Physico-chemical and sensory attributes of low-sodium restructured caiman steaks containing microbial transglutaminase and salt replacers. Meat Sci 96(1): 509-513.

CARdello HMAB, Silva MAAP AND DAMÁSIO MH. 2003. Programa Sistema de Coleta de Dados Tempo-Intensidade. Boletim SBCTA 37: 54-60.

Cruz aG, CAdena RS, Castroc WF, Esmerinoa EA, RodRIGUES JB, GAZE L, FARIA JAF, FREITAS MQ, DELIZA R AND BOLINI HMA. 2013. Consumer perception of probiotic yogurt: Performance of check all that apply (CATA), projective mapping, sorting and intensity scale. Food Res Int 54: 601-610.

Dos Santos BA, Campagnol PC, Morgano MA AND POLLONIO MA. 2013. Monosodium glutamate, disodium inosinate, disodium guanylate, lysine and taurine improve the sensory quality of fermented cooked sausages with $50 \%$ and $75 \%$ replacement of $\mathrm{NaCl}$ with $\mathrm{KCl}$. Meat Sci 96(1): 509-513. 
DRAKE SL, LOPETCHARAT K AND DRAKE MA. 2011. Salty taste in dairy foods: Can we reduce the salt? J Dairy Sci 94: 636-645.

CRUZ AG, FARIA JAF, POLlONIO MAR, Bolini HMA, CELEghini RMS, GRANATO D AND SHAH N. 2011. Cheeses with reduced sodium content: Effects on functionality, public health benefits and sensory properties. Trends in Food Science and Technology 2011(22): 276-291.

FERREIRA DF. 2002. SISVAR - Sistemas de análises de variância para dados balanceados: programa de análises estatísticas e planejamento de experimentos. Versão 4.3, Lavras: UFLA.

FORMAKER BK. AND HILL DL. 1988. An analysis of residual $\mathrm{NaCl}$ taste response after amiloride. American Physiological Society 255: 1002-1007.

FORTES ACB. 2012. Percepção sensorial e análise química de tempero e sal hipossódico como alternativas para dietas hipossódicas. Revista da Universidade Vale do Rio Verde 10(2): 164-172.

Grummer J, Bobowski N, Karalus M, Vickers Z AND SCHOENFUSS TC. 2013. Use of potassium chloride and flavor enhancers in low sodium Cheddar cheese. J Dairy Sci 96: 1401-1418.

GRUMmer J, Karalus M, ZHANG K, Vickers Z AND SCHOENFUSS TC. 2012. Manufacture of reduced-sodium Cheddar-style cheese with mineral salt replacers. J Dairy Sci 95: 2830-2839.

GuINEE TP AND O'KenNEDY BT. 2007. Mechanisms of taste perception and physiological controls. Guinee TP and O'Kennedy BT. Reducing salt in foods: Practical strategies, CRC Press, Boca Raton LA, USA, p. 246-287.

HEANEY RP. 2006. Role of dietary sodium in osteoporosis. J Am Col Nutr 25(3): 271S-276S.

Horita CN, Morgano MA, CEleghini RMS ANd Pollonio MAR. 2011. Physico-chemical and sensory properties of reduced-fat mortadella prepared with blends of calcium, magnesium and potassium chloride as partial substitutes for sodium chloride. Meat Sci 89: 426-433.

JOHNSON MER, KAPOOR DJ, MCMAHON DR, MCCOY RG AND NARASIM MON. 2009. Reduction of sodium and fat levels in natural and processed cheeses: Scientific and Technological aspects. Comp Rev Food Sci Food Saf 8: 252-268.

JORNAL FOLHADE SÃo PAULO. 2013. [cited 2013 Aug. 25]. Available from: http://www1.folha.uol.com.br/equilibrioesaude/ 2013/07/1314065-um-quarto-do-sodio-ingerido-nobrasil-vem-de-comida-processada.shtml.

Kamleh R, Olabi A, Toufeili I, Najm NEO, Younis T AND AJIB R. 2012. The effect of substitution of sodium chloride with potassium chloride on the physicochemical, microbiological, and sensory properties of Halloumi cheese. J Dairy Sci 95: 1140-1151.

KARIMI R, MORTAZAVIAN AM AND KARAMI M. 2012. Incorporation of Lactobacillus casei in Iranian ultrafiltered Feta cheese made by partial replacement of $\mathrm{NaCl}$ with KCl. J Dairy Sci 95: 4209-4222.

KATSIARI MC, ALICHANNIDIS E, VOUTSINAS LP AND ROUSSIS IG. 2001. Proteolysis in reduced sodium Kefalogravieira cheese made by partial replacement of $\mathrm{NaCl}$ with $\mathrm{KCl}$. Food Chem 73: 31-43.
KAWAMURA Y AND KARE MR. 1987. Umami: a basic taste, New York: Marcel Dekker.

Kenten C, Boulay A AND Rowe G. 2013. Salt. UK consumers' perceptions and consumption patterns. Appetite 73: 51-57.

MACFIE HJ, BRATCHELl N, GREENHOFF K. AND VALlis L. 1989 Designs to balance the effect of order of resentation and first-order-carry-over effects in hall tests. J Sens Stud 4: 129-148.

MATTES RD. 2001. The taste of fat elevates postprandial triacylglycerol. Physiological Behavior 74: 343-348.

MCCAUGHY S. 2007. Mechanisms of taste perception and physiological controls. In: Guinee TP and O'Kennedy BT. Reducing salt in foods: Practical strategies, CRC Press, Boca Raton LA, USA, p. 77-98.

Mendoza JE, SCHRAM GA, ARCAND J, Henson S AND L'ABBE M. 2014. Assessment of consumers' level of engagement in following recommendations for lowering sodium intake. Apetite 73: 51-57.

Mojet J, Heidema J AND Christ-Hazelhof E. 2004. Effect of concentration on taste-taste interactions in foods for elderly and young subjects. Chem Senses 29: 671-681.

Mooster G. 1980. Membrane transitions in taste receptor cell activation by sodium salts. In: Kare MR, Fregly MJ and Bernard RA. Biological and behavioural aspects of salt intake, Academic Press Inc, New York, p. 275-287.

NASCIMENTO R, CAMPAGNOL PCB, MONTEIRO ES AND POLLONIO MAR. 2007. Substituição de cloreto de sódio por cloreto de potássio: Influência sobre as características físico-químicas e sensoriais de salsichas. Alim Nutr 18(3): 297-302.

NEWSON RS ET AL. 2013. Barriers for progress in salt reduction in the general population. An international study. Apetite 71: $22-31$.

NunEs CA AND PINHEIRO ACM. 2012. SensoMaker, version 1.0. 2012, Lavras:UFLA.

PALAZZO AB AND BolINI HMA. 2009. Multiple time-intensity analysis and acceptance of raspberry-flavored gelatin. J of Sens Stud 24: 648-663.

Petersen KS, Torpy DJ, Chapman IM, Guha M, Clifton PM, TURNER K AND KeOGH JB. 2013. Food label education does not reduce sodium intake in people with type 2 diabetes mellitus. A randomised controlled trial. Appetite 68: 147-151.

Pineau N, Schlich P, CoRdelle S, Mathonnière C, ISSANCHOU S, IMBERT A, ROGEAUX M, ETIÉVANT P AND KÖSTER E. 2009. Temporal Dominance of Sensations: Construction of the TDS curves and comparison with timeintensity. Food Qual Prefer 20: 450-455.

RUUSUNEN M AND PUOLANNE E. 2005. Reducing sodium intake from meat products. Meat Sci 70: 531-541.

Sinufe GA, Zorrilla SE ANd Rubiolo AC. 2003. Casein degradation of Fynbo cheese salted with $\mathrm{NaCl} / \mathrm{KCl}$ brine and ripened at various temperatures. J Food Sci 68(1): 17-23.

SoLMS J. 1969. The taste of amino acids, peptides, and proteins. J Agr Food Chem 17: 686-688. 
Souza VR, Marques TV, GONCALVES CS, CARNEIRO JDS, PINHEIRO ACM AND NUNES CA. 2013. Salt equivalence and temporal dominance of sensations of different sodium chloride substitutes in butter. J Dairy Res 1-7.

Souza VR, PEReIra PAP, PINHEIRo ACM, Bolini HMA, BORGES S AND QUEIROZ F. 2012. Analysis of various sweeteners in low-sugar mixed fruit jam: equivalent sweetness, time-intensity analysis and acceptance test. Intern J Food Sci Technol 48: 1541-1548.

STONE H AND SIDEL JL. 1993. The role of sensory evaluation in the food industry. Food Qual and Prefer 4: 65-73.

TeOdoro STL, De SOUZA VR, NunEs CA AND PINHEIRo ACM. 2013. Equivalence salting and temporal dominance of sensations analysis for different sodium chloride substitutes in cream cheese. Int J Dairy Technol 67: 31-38.

TOLDRÁ F. 2006. Dry-cured ham. In: Hui YH et al. (Eds), Handbook of Food Science, Technology and Engineering, CRC Press, Boca Raton, 4, p. 16411.
VICKERS Z. 1988. Sensory specific satiety in lemonade using a just right scale for sweetness. J Sens Stud 3(1): 1-8.

WAKELING IN AND MACFIE JH. 1995. Designing consumer trials balaced for first and higher orders of carry-over effect when only a subset of $\mathrm{k}$ samples from $\mathrm{t}$ may be tested. Food Qual Prefer 6: 299-308.

WASH - WORD ACTION ON SALT AND HEAlth. 2012. Brazil Salt Action. [cited 2014 Mar. 11]. Avaiable: http://www. worldactiononsalt.com/worldaction/southamerica/73472. html

Ye Q, HeCK GL AND Desimone JA. 1991.The anion paradox in sodium taste reception: resolution by voltage-clamp studies. Science 254: 726-742.

YE Q, HeCK GL AND DesimOne JA. 1993. Voltage dependence of the rat chorda tympani response to $\mathrm{Na}+$ salts: implications for the functional organization of taste receptor cells. J Neurophysiol 70: 167-178. 
